\title{
Henkilöstökoulutuksen tämän hetken ongelmia
}

\author{
Virkkunen, Jaakko. 1981. Henkilöstökoulutuksen tämän hetken ongelmia. Aikuis- \\ kasvatus 1,2, 51-53. - Henkilöstökoulutuksen tärkeimmäksi ongelmaksi nähdään \\ pätevän toimintaa ohjaavan ammattiopetuksen didaktiikkaa koskevan teoreettisen tie- \\ don ja tutkimuksen puuttuminen. Tällöin sattumanvaraisesti valitaan koulutusta kos- \\ kevat mallit ja teoreettiset näkemykset. Koska henkilöstökoulutukselta vaaditaan yhä \\ suurempaa tehokkuutta, tarvitaan sen suunnittelun pohjaksi teoreettisesti perusteltua \\ didaktista kokonaisnäkemystä ja entistä laajempaa tieteellisen tiedon soveltamista.
}

\section{Henkilöstökoulutus - aikuiskoulutusta ja yritysten sisäistä hallintoa}

Työnantaja hankkii tai järjestää palveluksessaan olevalle henkilöstölle koulutusta pitääkseen tämän toiminnan asettamien vaatimusten ja ammatillisen kehityksen tasalla. Koulutuksen järjestäminen poikkeaa yleensä varsin paljon yrityksen tai viraston varsinaisten tehtävien hoidosta. Siksi henkilöstön pätevyydestä pyritään yleensä huolehtimaan ensisijassa hankkimalla koulutuspalveluja organisaation ulkopuolelta. Monet koulutustarpeista ovat kuitenkin sellaisia, että tarvittava opetus on järjestettävä itse. Yksi viime vuosikymmenien aikana nopeasti kehittyneistä aikuiskoulutuksen sektoreista onkin juuri työyhteisöjen sisäinen koulutus.

Ammatillisen aikuiskoulutuksen yleiset tämänhetken ongelmat heijastuvat myös henkilöstökoulutukseen. Tärkein näistä ongelmista on ehkä pätevän työtä ohjaavan ammattiopetuksen didaktiikkaa koskevan teoreettisen tiedon ja tutkimuksen puute. Organisaation sisäisen koulutuksen erityiset ongelmat liittyvät siihen, että se on paitsi aikuiskoulutusta myös kiinteä osa organisaation johtamista ja sisäistä hallintoa. Niinpä henkilöstökoulutuksen tavoitteet määräytyvät organisaation tavoitteista ja organisaation toiminnan esiin nostamista vaatimuksista. Yksilön persoonallisuuden kehittämiseen liittyvät näkökohdat ovat henkilöstökoulutuksessa yleensä selvästi työyksikön toiminnallisille tavoitteille alistettuja.

Henkilöstökoulutuksella ei yleensä pyritä antamaan yleistä ammattipätevyyttä, vaan valmiuksia, jotka vastaavat organisaatiossa esiintyviä tehtäväkokonaisuuksia tai yksittäisiä työ- tehtäviä. Koulutuksella täydennetään yleisen ammatillisen koulutuksen luomaa pätevyyttä yksikkökohtaisilla erityistiedoilla ja -taidoilla sekä teknologian ja työnjaon vähäisten muutosten edellyttämillä uusilla valmiuksilla. Varsinaisten kvalifikaatiotavoitteiden ohella koulutukseen liittyy usein erilaisia hallinnollisia sivutavoitteita kuten esimerkiksi henkilöstön valinta ja arviointi koulutuksen yhteydessä taikka toiminnan, uusien järjestelyiden tai suunnitelmien kriittinen käsittely sekä ideoiden tuottaminen suunnittelua ja kehittämistyötä varten. Varsin usein opetuksen sisältönä ovat organisaation sisäiset ohjeet, tulkinnat ja menettelytavat.

Opiskelu ei henkilöstökoulutuksessa ole oppilaiden elämää jäsentävä päätoiminta, niin kuin nuorisoasteen koulutuksessa. Siksi opetus on kyettävä niveltämään oppilaiden työn ja organisaation toiminnan asettamiin vaatimuksiin. Tämän vuoksi opetuksen ajallisiin, fyysisiin, sosiaalisiin, taloudellisiin, hallinnollisiin järjestelyihin liittyvät kysymykset muodostuvat hyvin keskeisiksi.

Siirtyminen opetuksesta opitun soveltamiseen ja käyttöön tapahtuu henkilöstökoulutuksessa yleensä hyvin välittömästi. Koska opetus liittyy läheisesti työhön, joudutaan erityistä huomiota kiinnittämään opetetun soveltamiseen ja taitojen harjoittamiseen. Erityisesti täydennyskoulutuksessa on tyypillisesti kysymys yleisten tietojen tai menetelmien soveltamisesta organisaation erityisiin olosuhteisiin. Tiedon ja ymmärtämisen lisäksi on päästävä käytännön taitoihin. Henkilöstökoulutuksen piirissä kehittyneet, sille tyypilliset koulutusmuodot ja koulutuksen suunnitteluun liittyvät ajattelutavat (työnohjaus, workshop-tilaisuu- 
det, mallien ja harjoituslaitteiden käyttöön perustuva opetus, ns. orgaaninen koulutus) keskittyvätkin juuri paljolti harjoittelun ja opetetun soveltamisen kysymyksiin.

\section{Henkilöstökoulutuksen piirissä vallitseva näkemys opetuksesta}

Koska henkilöstökoulutus on osa organisaation hallintoa ja johtamista, sen ongelmiakin on tarkasteltu ensisijassa hallinnollisin käsittein. Valtaosa henkilöstökoulutuksen piirissä työskentelevistä on siirtynyt tehtäviin joko tietyn alan ammattitehtävistä tai hallinnollisista tehtävistä. Varsin suuri osa osallistuu koulutuksen järjestämiseen varsinaisten ammattitehtäviensä ohessa. Vain pieni osa henkilöstökoulutuksen parissa työskentelevistä on perehtynyt kasvatustieteeseen ja didaktiikkaan. Niinpä käsitys koulutuksesta ja koulutuksen järjestämiseen liittyvät käytännöt ovat muotoutuneet arkiajattelun ja hallinnollisten näkökohtien perusteella lähes täysin ilman yhteyttä opetusta ja tehokkaan opetuksen ehtoja tutkivaan tieteenalaan, didaktiikkaan. Didaktisen kokonaisnäkemyksen sijasta työkäytäntöjä ovat ohjanneet yksittäiset koulutusta koskevat mallit ja teoreettiset näkemykset, joita on pyritty yhdistämään ja soveltamaan rinnakkain välittämättä niiden teoreettisten lähtökohtien eroista ja usein täydellisestä vastakkaisuudestakaan. (Ks. esim. Söderström 1979)

Tärkeimpiä liikkeenjohdollisten teorioiden ohella henkilöstökoulutukseen vaikuttaneista opetuksen suunnittelua ja toteutusta koskevista näkemyksistä ovat toisaalta koulutusteknologia ja toisaalta ryhmä- ja tunnekeskeinen koulutusajattelu, joka pohjautuu sosiaalipsykologiseen pienryhmäteoriaan ja rogresilaiseen existenttiaalistiseen psykologiaan sekä ns. nondirektiivisestä terapiasta saatuihin kokemuksiin. Näennäisestä vastakkaisuudesta huolimatta näillä näkemyksillä on eräitä olennaisia yhtymäkohtia. Molemmat tarkastelevat oppimista käyttäytymisen muutoksena. Ne eivät kiinnitä huomiota tietoiseen toimintaan ja sen perustana oleviin jäsentyneisiin tietoihin ja käsityksiin. Johdonmukaisen ajattelun ja selkeän kokonaiskäsityksen sijasta ne keskittävät huomionsa ulkoisen käyttäytymisen muuttamiseen tai erillisten, emotionaalisesti merkittävien kokemusten aikaansaamiseen. Molemmat suunnat hylkäävät käytännössä käsityksen opetussisällöstä tietyn rakenteen omaavana sivistysaineksena ja kiinnittävät ylipäätään hyvin vähän huomiota opetussisältöihin ja opetussuunnitelmateorian klassisiin kysymyksiin kuten oppiaineksen rakenteen erittelyyn tai teorian ja käytännön suhteen ongelmaan. Niissä nähdään opetuksen tehokkuuden riippuvan ensisijassa opetusmenetelmistä ja toteuttamistavoista, joita tarkastellaan usein opetussisällöistä irroitettuina.

Näistä eri lähtökohdista on muotoutunut henkilöstökoulutuksen piirissä vallitseva käsitys opetuksesta ja tehokkaan opetuksen edellytyksistä. Sille on tyypillistä arkikokemuksen ja välittömän käytännöllisyyden voimakas korostaminen. Opetuksen ajatellaan olevan sitä tehokkaampaa mitä selvemmin se keskittyy välittämään työssä saavutettuja käytännön kokemuksia ja opettamaan kädestä pitäen valmiita toimintamalleja ja käytännön ratkaisuja. Teoreettisuus ymmärretään usein käytännön toiminnan kannalta merkityksettömäksi verbalistiikaksi ja sitä pidetään lähes opetuksen tehottomuuden ja elämälle vierauden synonyymina tekemättä eroa hyvän ja huonon teorian tai käytännön kannalta merkitsevän ja asiaan kuulumattoman teorian välillä. Näin opetuksen tavoitteet on rajattu erittäin suppeisiin, arkiajattelun määrittelemiin lähtökohtiin sen sijaan, että yhä polttavampia opetuksen tehokkuuden ongelmia olisi pyritty ratkaisemaan opetusta koskevan tieteellisen tiedon perusteella. Näin on päädytty henkilöstökoulutuksen tämän hetkiseen perusongelmaan, joka liittyy koulutukselle asetettujen yhä kasvavien tehokkuus- ja vaikuttavuusvaatimusten ja tehokkaan oppimisen edellytyksiä koskevan asiantuntemuksen väliseen epäsuhtaan.

\section{Mille pohjalle henkilöstö- koulutuksen pitkäjänteinen kehittäminen voi rakentua}

Koulutuksen kannalta yksi olennaisemmista työelämän tämän hetkisistä tunnuspiirteistä on tieteellisen tiedon ja tekniikan kiihkeä kehitysvauhti, joka asettaa koko työyhteisölle ja sen piirissä toimiville eri ammattialojen edustajille entistä suurempia joustavuuden ja uudistumiskyvyn vaatimuksia. Uusi tieto ja uudet työmenetelmät eivät useinkaan synny työyhteisön sisällä, vaan ne ovat tulosta laajasta eri organisaatioissa ja eri maissa tapahtuvasta tutkimusja kehittämistyöstä. Kansainvälisen kehityksen tasolla pysyminen ja uuden tiedon nopea soveltaminen edellyttää henkilöstöltä kykyä itsenäiseen työskentelyyn, oma-aloitteiseen kehi- 
tyksen seuraamiseen ja työtapojen joustavaan uudistamiseen. Tämä kaikki on mahdollista vain laajan ja syvän asiantuntemuksen, työn kannalta olennaisten tiedonalojen syvällisen hallinnan avulla.

Henkilöstökoulutuksen piirissä nykyisin vallitseva organisaatiokeskeinen, erillisten käytännön tietojen ja menettelytapojen välittämiseen keskittyvä ote on jyrkässä ristiriidassa työelämän yleisen kehityksen asettamien vaatimusten kanssa. Yksittäisten menetelmien ja tietojen sijasta koulutuksen tulisi antaa laajaalaista, jäsentynyttä tietoa työn kannalta olennaisilta aloilta. Jotta henkilöstökoulutus voisi tältä kannalta täyttää tehtävänsä, sen piirissä työskentelevien tulisi yhtäältä luopua vallitsevasta tavasta nähdä opetus ensisijassa käyttäytymisen muovaamisena ja korvata se klassillisen didaktiikan käsityksellä opetuksesta sivistyksen ja kasvatuksen päämuotona. Toisaalta tarvitaan uutta didaktista kokonaisnäkemystä, joka keskittyy erityisesti ammatillisessa toiminnassa ja työelämän organisaatioiden johtamisessakin yhä keskeisemmäksi tulevan tieteeìlisen tiedon opettamisen ja itsenäisen hallinnan kysymyksiin.

Opetusta koskeva kokonaisnäkemys voi rakentua vain ihmisen käsitteellistä ajattelua ja siihen perustuvaa oppimista koskevaan tietoon eli ns. kognitiiviseen teoriaan. Tämän kaltaisen uuden koulutusnäkemyksen muodostumisesta on olemassa selviä merkkejä. Henkilöstökouluttajien piirissä on herännyt kiinnostus kognitiiviseen oppimisteoriaan (oppimisteoriat ja henkilöstökoulutus ks. esim. Jones 1979) ja didaktiikkaan ja myös käytännössä on etsitty uudenlaisia, laajojen tiedon kokonaisuuksien hallintaan tähtääviä opetuksen muotoja. Esimerkkinä tällaisesta voidaan pitää esim. työvoimaministeriön henkilöstökoulutuksessa kokeiltuja ns. lukukursseja, joissa suppeiden kontaktiopetustilaisuuksien välillä opiskellaan n. 1500 sivua aiheeseen liittyvää kirjallisuutta.

Henkilöstökoulutuksen ajankohtaisten tehokkuusongelmien ratkaisemiseksi on kehitelty erilaisia harjoittavan opetuksen menetelmiä, soveltamiseen keskittyviä uusia koulutusmuotoja ja työn asettamiin vaatimuksiin soveltuvia opetuksen organisointitapoja. Perusongelma tällä hetkellä on kuitenkin siinä, että näiden erilaisten osaratkaisujen käyttöä ei ohjaa kyllin laaja ja johdonmukainen didaktinen kokonaisnäkemys. Sellaisen puuttuessa ajaudutaan helposti korostamaan suhteettomasti joidenkin yksittäisten kysymysten, menetelmien, näkökulmien, tai ulkoisten muotojen merkitystä.

\section{Lähteet:}

Jones, Merrick. 1979. Training Practices and Learning Theories. Journal of European Industrial Training. Vol 3, No 7.

Söderström, M. 1979. Personalutbildning och personalutvecling. Liber förlag, Stockholm. 